\title{
The Effect of Endozym $\beta$-split, a Commercial Enzyme Preparation Used for Aroma Release, on Tannat Wine Glycosides
}

\author{
A.G. Cid*, M.C. Goldner, M. Daz, G. Ellenrieder
}

INIQUI (Instituto Nacional de Investigaciones para la Industria Química), Universidad Nacional de Salta - CONICET. Av. Bolivia 5150, 4400 Salta, Argentina

Submitted for publication: February 2011

Accepted for publication: December 2011

Key words: Glycosidases, inhibition, glycosides hydrolysis, Tannat wine, aroma

\begin{abstract}
Commercial preparations with glycosidase activities are used to enhance wine aroma, but they are not extensively characterized. The aim of this work was to study the effect of three enzymes on aroma improvement in Tannat red wine. After the selection of the most appropriate enzyme for further testing, its effectiveness on the hydrolysis of the total glycosides present in Tannat wine was measured. The three preparations showed high $\beta$-glucosidase and $\alpha$-arabinosidase activities (in the range of 10 to $174 \mathrm{U} / \mathrm{mL}$ or $\mathrm{U} / \mathrm{g}$ ), but very low levels of $\alpha$-rhamnosidase (less than $1 \mathrm{U} / \mathrm{mL}$ ). The $\beta$-glucosidases studied remained active in the presence of Tannat wine. The selected enzyme, Endozym $\beta$-split, supplemented with $\alpha$-rhamnosidase, resulted in almost $30 \%$ hydrolysis of the glycosides in Tannat wine, when added at a concentration higher than that recommended by the manufacturers. A sensory evaluation showed that the enzyme-treated wines were significantly different from the controls, suggesting that at least a part of the hydrolyzed glycosides in the Tannat wine were aroma precursors. However, it cannot be assumed that all commercial enzymes would be effective in hydrolyzing aroma precursors just because they show glycosidase activities. Higher concentrations of Endozym $\beta$-split than that recommended by the manufacturer are necessary to reach an appreciable level of glycoside hydrolysis. Supplementation of Endozym $\beta$-split with $\alpha$-rhamnosidase is recommended in this enzyme - wine system for the greater release of the aroma from the glycosidicallybound precursors.
\end{abstract}

\section{INTRODUCTION}

Musts and fruit juices contain small quantities of a wide range of glycosides, which remain non-hydrolyzed after vinification (Gunata et al., 1988). Some of these glycosides are aroma precursors because their aglycones are aromatic compounds. They are mainly the $O-\beta$-D-glucosides and the $O$-diglycosides: $\alpha$-L-arabino- $\beta$-D-glucosides, $\alpha$-Lrhamno- $\beta$-D-glucosides and $\beta$-D-apio- $\beta$-D-glucosides. Aglycones, which are always directly bound to glucose, are mainly monoterpenes, C13-norisoprenoids and benzene derivatives (Williams et al., 1982; Gunata et al., 1985; Sarry \& Gunata, 2004). Since only partial hydrolysis occurs during vinification, some of these glycosides remain in the wine as a potential source of aroma to be exploited. Thus, hydrolysis of these compounds using exogenous glycosidases may result in an improvement of wine aroma (Cabaroglu et al., 2003; Sánchez Palomo et al., 2005). Most of the enzymes hydrolyzing diglycosides act sequentially; in the first step $\alpha$-L-rhamnosidase (EC 3.2.1.40), $\alpha$-L-arabinosidase (EC 3.2.1.55) or $\beta$-D-apiosidase liberate the corresponding sugar and a glucoside, which is subsequently hydrolyzed by $\beta$-Dglucosidase (EC 3.2.1.21) (Gunata et al., 1988).
Commercial enzymes employed in winemaking (Martino et al., 1996; Guo et al., 1999; Cabaroglu et al., 2003; Tamborra et al., 2004) and other glycosidases produced by bacteria (Michlmayr et al., 2010), yeast (Arévalo Villena et al., 2007) or fungi(Le Traon-Masson \& Pellerin, 1998) were tested for their glycosidase activity, for aroma enhancement in white and red wines produced from several cultivars.

Even though there are numerous published studies related to the use of exogenous glycosidases to enhance wine aroma, there were no commercially available enzymes for this purpose until a few years ago. Only preparations with pectolytic, hemicellulolytic and cellulolytic activities to improve extraction and clarification steps were being promoted to hydrolyze aroma precursors, due to their secondary glycosidase activities. Although these older commercial enzymes showed high glucosidase and arabinosidase activities, they had low levels of rhamnosidase and apiosidase (Dupin et al., 1992) and their glycosidase activities were not extensively characterized. In recent years specific enzymes to enhance wine aroma have appeared on the market, but there is little or no information about 
their glycosidase activity, stability or inhibition by wine compounds.

Endozym Rouge is an enzymatic preparation suitable for color and aroma extraction from red grapes, due to its pectinolytic, cellulolytic and hemicellulolytic activities. Its additional value for aroma liberation is also recommended by its manufacturer (www.aeb-group.com). Guérin et al. (2009) found that among several preparations for color extraction, Endozym Rouge had considerable $\beta$-glucosidase and $\alpha$-arabinosidase activities, but low levels of $\alpha$-rhamnosidase and $\beta$-apiosidase. However, we found that its $\beta$-glucosidase was highly inhibited by wine compounds and could hardly act efficiently in the hydrolysis of aroma precursors (Cid \& Ellenrieder, 2009).

Although Endozym $\beta$-split, Endozym ICS 10 Arome and Endozym cultivar are pectolytic enzymes, they are promoted to extract aroma precursors or to liberate aroma compounds from these glycosidic precursors. The presence of $\beta$-glucosidase activity in all of these preparations is emphasized by the manufacturers (www.aeb-group.com), but the actual activity values are not mentioned. There are only a few studies of these commercial preparations, especially with regard to their capacity to hydrolyze glycosidic precursors. Armada et al. (2010) studied the effect of Endozym cultivar on the extraction of aromatic compounds during maceration, and Guérin et al. (2009) quantified different activities in the same preparation, including glycosidases, but there is no published data that we know of that address the inhibition or stability of these enzymes in the presence of wine, or about their effect on wine glycosides.

Red wines made from Vitis vinifera cv. Tannat are produced in Uruguay, and are the wines most representative of this country. Even though Vitis vinifera cv. Tannat has been cultivated for several years in Salta, Argentina, until a few years ago there were no red wines produced in Argentina from this grape variety. Little information is available about wines made from this varietal. Boido et al. (2003) characterized the aroma composition of Vitis vinifera cv. Tannat and studied the effect of a $\beta$-glucosidase from Oenococcus oeni on glycosidic precursors during malolactic fermentation (Boido et al., 2002). In a previous study we tested some glycosidase activities on synthetic substrates in Tannat wine (Cid \& Ellenrieder, 2009).

In order to predict the behavior of these newer enzymes on the hydrolysis of natural glycosides in wines, three commercial preparations for aroma enhancement, Endozym $\beta$-split, Endozym ICS 10 Arome and Endozym cultivar, were studied and compared with an enzyme used to improve color extraction from grapes, Endozym Rouge. The main aroma releasing glycosidases, their optimum $\mathrm{pH}$ for activity and the inhibition produced by Tannat wine were determined using synthetic substrates of the $p$-nitrophenylglycoside type. Based on the observed results, one preparation was selected for a study of its effect on the glycoside concentration in Tannat wine. The effectiveness on glycoside hydrolysis in wine was compared to the concentrations recommended by the manufacturers and by other studies of wine aroma enhancement. Finally, samples of untreated and treated wine were submitted to a sensory analysis using a triangle test.

\section{MATERIALS AND METHODS \\ Materials}

Tannat red wine was produced by a local winery in Cafayate, Salta, Argentina. In addition $p$-nitrophenyl$\beta$-D-glucopyranoside $\quad(p \mathrm{NPG}), \quad p$-nitrophenyl- $\alpha-\mathrm{L}$ rhamnopyranoside ( $p$ NPR) and $p$-nitrophenyl- $\alpha-\mathrm{L}$ arabinofuranoside ( $p$ NPA) were supplied by Sigma (St. Louis, MO, USA), $p$-nitrophenol ( $p$ NP) by Merck (Darmstadt, Germany), Amberlite XAD-2 by Supelco (Bellefonte, PA, USA) and acetonitrile HPLC grade by Carlo Erba (Rodano, Italy). The enzymatic kit for glucose determination was purchased from Wiener Laboratorios (Rosario, Argentina).

Endozym cultivar, Endozym ICS 10 Arome, Endozym $\beta$-split and Endozym Rouge were commercial enzymes from Pascal Biotech (Paris, France) that are used in the winemaking industry. The $\alpha$-rhamnosidase HPS 11518 was from Tanabe (Japan). All enzymes were produced by Aspergillus niger. All the other reagents were analytical grade.

\section{Enzyme assays \\ Spectrophotometric assays}

The activity of $\beta$-D-glucopyranosidase ( $\beta$-glu), $\alpha$-Lrhamnopyranosidase ( $\alpha$-rham) and $\alpha$-L-arabinofuranosidase $(\alpha$-ara) was determined by taking out samples from the reaction medium at different time intervals during 10 minutes and measuring the absorbance of the produced $p$-nitrophenol in basic medium at its absorbance maximum, $400 \mathrm{~nm}$, using the corresponding synthetic substrate, $1.9 \mathrm{mM}$ $p$ NPG, $2.4 \mathrm{mM} p$ NPR or $1 \mathrm{mM} p \mathrm{NPA}$, respectively (Cid \& Ellenrieder, 2009). Activity units (U) expressed as $\mu \mathrm{mol} / \mathrm{min}$ were calculated from the slope, taking a molar absorptivity, $\varepsilon$, of $16.44 \mathrm{mM}$.

\section{Chromatographic assays}

When $p$ NP could not be measured spectrophotometrically due to the presence of colored substances absorbing at 400 $\mathrm{nm}$, it was quantified by HPLC in an acidic medium as previously described (Cid \& Ellenrieder, 2009).

\section{Glycosidases in commercial preparations}

The activity of $\beta$-D-glucopyranosidase, $\alpha$-L-rhamnopyranosidase and $\alpha$-L-arabinofuranosidase at $50^{\circ} \mathrm{C}$ was measured spectrophotometrically in the commercial enzymes Endozym $\beta$-split, Endozym ICS 10 Arome, Endozym cultivar and Endozym Rouge using the appropriate synthetic substrates. Optimum $\mathrm{pH}$ of $\beta$-D-glucopyranosidases and $\alpha$-L-arabinofuranosidases was determined at $50^{\circ} \mathrm{C}$ by measuring these activities in $50 \mathrm{mM}$ citric acid/ $\mathrm{Na}$ citrate buffer in a range of $\mathrm{pH}$ from 3.0 up to 5.0 as described above.

\section{Glycosidase inhibition by Tannat wine}

Endozym $\beta$-split, Endozym ICS 10 Arome, Endozym cultivar and Endozym Rouge $\beta$-glucosidase activity on $2 \mathrm{mM} p \mathrm{NPG}$ at $50^{\circ} \mathrm{C}$ in $60 \mathrm{mM}$ tartaric acid/Na tartrate buffer $\mathrm{pH} 3.6$ with or without $50 \%$ Tannat red wine in the reaction medium was measured chromatographically. Endozym $\beta$-split and Endozym Rouge $\alpha$-arabinosidase on $1 \mathrm{mM} p \mathrm{NPA}$ at $50^{\circ} \mathrm{C}$ was also determined by HPLC in the same buffer with or without $50 \%$ Tannat wine. 


\section{Glycoside hydrolysis in Tannat wine at different enzyme concentrations}

According to the concentration recommended by the manufacturer (www.aeb-group.com), $12.5 \mu \mathrm{L}$ Endozym $\beta$-split and $1.76 \mu \mathrm{L}$ HPS 11518 were added to $250 \mathrm{~mL}$ of Tannat red wine. In another experiment $172 \mu \mathrm{L}$ Endozym $\beta$-split and $24 \mu \mathrm{L}$ HPS 11518 were added to the same volume of wine to reach concentrations similar to those used by other studies (Gunata et al., 2000; Martino et al., 2000). Samples and a control without enzymes were incubated at $20^{\circ} \mathrm{C}$ and the remaining glycoside concentration measured after 12 days.

\section{Glycoside extraction and quantification}

Wine glycosides were extracted following a procedure described by Gunata et al. (1985) and Williams et al. (1995) by adsorbing them selectively on Amberlite XAD-2. The column $(80 \mathrm{~mm} \times 0.6 \mathrm{~mm}$ i.d. $)$ was pre-treated six times with $10 \mathrm{~mL}$ methanol and six times with $10 \mathrm{~mL}$ diethyl ether, and then washed six times with $10 \mathrm{~mL}$ water. After $5 \mathrm{~mL}$ of wine was loaded the resin was washed with $10 \mathrm{~mL}$ water and eluted with $7 \mathrm{~mL}$ methanol.

Glycoside fractions, after solvent evaporation, were redissolved in $0.5 \mathrm{~mL}$ of $27 \%$ ethanol in water and glycosides were determined according to Arévalo Villena et al. (2006). Also, $0.5 \mathrm{~mL} 2.25 \mathrm{M} \mathrm{H}_{2} \mathrm{SO}_{4}$ was added to $0.25 \mathrm{~mL}$ of samples to give solutions for hydrolysis containing $1.5 \mathrm{M}$ $\mathrm{H}_{2} \mathrm{SO}_{4}$. A control solution for determination of free glucose concentration was prepared by adding water instead of $\mathrm{H}_{2} \mathrm{SO}_{4}$. The samples were boiled for $1 \mathrm{~h}$, while controls were held at room temperature. Released glucose was measured using a glucose oxidase assay kit after neutralizing the acid with an equal volume of $3 \mathrm{M} \mathrm{NaOH}$.

\section{Sensory analysis}

Samples of wine, incubated with enzymes $(688 \mu \mathrm{L} / \mathrm{L}$ Endozym $\beta$-split and $96 \mu \mathrm{L} / \mathrm{L}$ HPS 11518 ) for 12 days, were submitted to an expanded triangle test (ASTM, 1977). The panel consisted of 16 judges, who had previous experience of wine sensory analysis. During the assessment, one session of 2 hours, each assessor performed two triangles. The 'believed' samples were selected by the assessors, who then described the perceived aroma and taste attributes.

\section{Physico-chemical determination}

Total and volatile acidities, $\mathrm{pH}$, alcohol level, reducing sugars and dry extract were determined in the enzyme-treated wines and controls according to the methods of the Association of Official Analytical Chemists (1990).

\section{Statistical analyses}

At least two replicates were measured in each determination. Statistical analyses were carried out using PRISM software (GraphPad, San Diego, CA, USA). Binomial distribution was used to calculate the significance level in the triangle test based on the number of correct answers. ANOVA analysis of the physico-chemical determinations was performed using Infostat software (Córdoba, Argentina).

\section{RESULTS AND DISCUSSION}

\section{Glycosidases in commercial preparations}

The commercial preparations Endozym Rouge, Endozym $\beta$-split, Endozym ICS 10 Arome and Endozym cultivar were tested for $\beta$-glucosidase, $\alpha$-arabinosidase and $\alpha$-rhamnosidase activities (Table 1). The first two activities were determined in buffer at the optimum $\mathrm{pH}$ (4.5 for the $\beta$-glucosidases and 4 for the $\alpha$-arabinosidases) and $50^{\circ} \mathrm{C}$ and the $\alpha$-rhamnosidase activity at $\mathrm{pH} 4$. Values of the expected activities in wines are also shown.

All of the preparations presented high values of $\beta$-glucosidase and $\alpha$-arabinosidase, but much lower levels of $\alpha$-rhamnosidase, which is consistent with data published on glycosidase activities in commercial preparations used in winemaking (Gunata et al., 1997; Sarry \& Gunata, 2004; Barbagallo et al., 2004; Pogorzelski \& Wilkowska, 2007). This result suggests that these enzymes would allow hydrolysis of only some of the glycosidic precursors, since those containing rhamnose linked to the $O$-D-glucoside would remain unchanged in wines.

The expected glycosidase activities in wine were calculated taking into account the activity at optimum $\mathrm{pH}$ and $50^{\circ} \mathrm{C}$ and the amount of enzyme per $\mathrm{hL}$ of wine recommended by the manufacturers: 2 to $5 \mathrm{ml} / \mathrm{hL}$ of Endozym $\beta$-split, 0.4 to $0.8 \mathrm{~mL} / \mathrm{hL}$ of Endozym ICS 10 Arome, 2 to $3 \mathrm{~g} / \mathrm{hL}$ of Endozym cultivar and 2 to $4 \mathrm{~g} / \mathrm{hL}$ of Endozym Rouge. The activities present in the wines would probably be insufficient to hydrolyze the glycosidic precursors, especially if we consider that these activities will be even

TABLE 1

Glycosidase activities in commercial preparations.

\begin{tabular}{|c|c|c|c|c|c|c|}
\hline \multirow{2}{*}{ Enzyme } & \multicolumn{3}{|c|}{ Activity $\left({ }^{\mathrm{a}} \mathrm{U} / \mathrm{mL} \text { or }{ }^{\mathrm{b}} \mathrm{U} / \mathrm{g}\right)^{1}$} & \multicolumn{3}{|c|}{ Maximum expected activity in wines $(\mathrm{U} / \mathrm{mL})\left(\mathrm{x} 10^{4}\right)^{2}$} \\
\hline & $\beta$-glu & $\alpha$-ara & $\alpha$-rham & $\beta$-glu & $\alpha$-ara & $\alpha$-rham \\
\hline E. $\beta$-split & $174.1 \pm 1.6^{\mathrm{a}}$ & $42.6 \pm 2.5^{\mathrm{a}}$ & $0.77 \pm 0.15^{\mathrm{a}}$ & 87.0 & 21.3 & 0.39 \\
\hline E. ICS 10 Arome & $67.4 \pm 0.7^{\mathrm{a}}$ & $165.0 \pm 3.0^{\mathrm{a}}$ & $0.80 \pm 0.05^{\mathrm{a}}$ & 5.4 & 13.2 & 0.06 \\
\hline E. cultivar & $10.6 \pm 0.3^{b}$ & $15.1 \pm 0.6^{\mathrm{b}}$ & n.d. & 3.2 & 4.5 & \\
\hline E. Rouge & $77.0 \pm 0.1^{\mathrm{b}}$ & $80.0 \pm 0.1^{\mathrm{b}}$ & $0.94 \pm 0.04^{\mathrm{b}}$ & 15.4 & 16.0 & 0.19 \\
\hline
\end{tabular}

${ }^{1}$ Activity at $50{ }^{\circ} \mathrm{C}$ in $50 \mathrm{mM}$ citric acid / Na citrate buffer at optimum $\mathrm{pH}$ for $\beta$-glucosidase ( $\beta$-glu) and $\alpha$-arabinosidase $(\alpha$-ara) and at $\mathrm{pH} 4$ for $\alpha$-rhamnosidase ( $\alpha$-rham)

n.d.: not detected

${ }^{2}$ Maximum expected activity in wines: Activity (at $50{ }^{\circ} \mathrm{C}$ and optimum $\mathrm{pH}$ for $\beta$-glu and $\alpha$-ara and at $\mathrm{pH} 4$ for $\alpha$-rham) $\mathrm{x}$ recommended dose

${ }^{\text {a }}$ Activity expressed as $\mathrm{U} / \mathrm{mL}$ for liquid preparations

${ }^{\mathrm{b}}$ Activity expressed as $\mathrm{U} / \mathrm{g}$ for powder preparations 
lower once the enzymes are added to the wines, where $\mathrm{pH}$ and temperature conditions are different from those shown in Table 1 and where there are several compounds that would act as inhibitors, such as ethanol, glucose and gluconolactone (Sarry \& Gunata, 2004; Cid \& Ellenrieder, 2009). In addition the activities of the glycosidases are usually higher on the synthetic than the natural substrates.

$\beta$-Glucosidase and $\alpha$-arabinosidase were assayed at $50^{\circ} \mathrm{C}$ in buffer at a $\mathrm{pH}$ range from 3 to 5 . Figures 1 and 2 show the relative activity as a percentage of the maximum value of activity observed for these enzymes. $\alpha$-Rhamnosidase was not tested because its presence was much lower than the other two activities.

It could be observed that the $\mathrm{pH}$ of maximum activity for the four $\beta$-glucosidases was 4.5 , while for the $\alpha$-arabinosidases it was 4.0. These values are similar to those found in other studies of glycosidases produced by fungi (Le Clinche et al., 1997; Le Traon-Masson \& Pellerin, 1998;

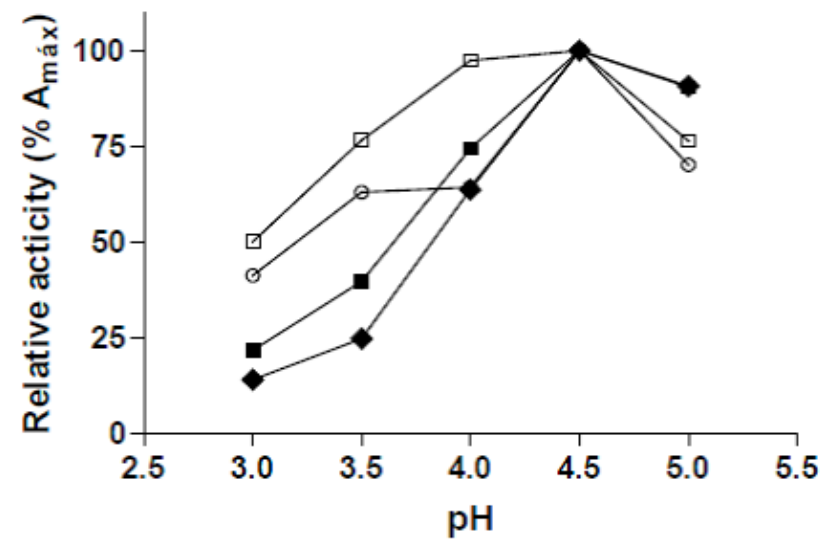

FIGURE 1

Influence of the $\mathrm{pH}$ on $\beta$-glu activities $50 \mathrm{mM}$ citric acid/citrate buffer, $50^{\circ} \mathrm{C}$

$\square$ Endozym $\beta$-split; $\circ$ Endozym ICS 10 Arome; a Endozym cultivar; Endozym Rouge.

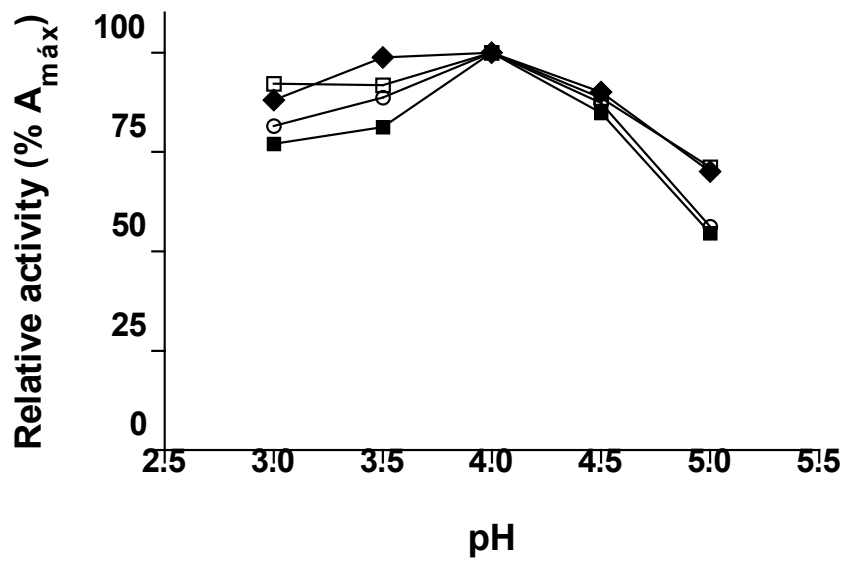

FIGURE 2

Influence of the $\mathrm{pH}$ on $\alpha$-ara activities $50 \mathrm{mM}$ citric acid/citrate buffer, $50^{\circ} \mathrm{C}$

$\square$ Endozym $\beta$-split; $\circ$ Endozym ICS 10 Arome; a Endozym cultivar; Endozym Rouge.
Saha, 2000). Among the different enzyme preparations, the $\beta$-glucosidase and the $\alpha$-arabinosidase from Endozym $\beta$-split had a higher relative activity when the $\mathrm{pH}$ was in the range of that found in wines ( 3 to 4 ), maintaining 50\% and $92 \%$ of their activities at $\mathrm{pH} 3$, respectively.

\section{Glycosidase inhibition by Tannat wine}

Taking into account the sequential mechanism for the hydrolysis of the glycosidic precursors (Gunata et al., 1988), the action of $\beta$-glucosidase is essential for the complete hydrolysis of all the glycosides and the consequent liberation of aroma compounds. However, among glycosidases to enhance wine aroma, $\beta$-glucosidase usually suffers the greatest inhibition and is the least stable (Sarry \& Gunata, 2004). For this reason, many studies about glycosidases focus on this activity.

Although testing the inhibition produced by ethanol, glucose and gluconolactone on $\beta$-glucosidase for $p$ NPG hydrolysis is a common practice, this information is not enough to predict its behavior in wine, since there are other compounds in this medium that can act as inhibitors of its activity (Cid \& Ellenrieder, 2009). Thus, when many enzymes are being compared, it should be appropriate to determine $\beta$-glucosidase activity on $p$ NPG in the presence of wine and to express the results as the relative activity to that in buffer solution under the same conditions to select the most appropriate enzyme preparation to choose.

Table 2 shows the values of $\beta$-glucosidase activity at $50^{\circ} \mathrm{C}$ on $2 \mathrm{mM} p \mathrm{NPG}$ for the four preparations in buffer and with 50\% Tannat wine added to the reaction medium.

This study was performed with only $50 \%$ wine added because the technique for measuring enzyme inhibition in $100 \%$ wine is prone to more errors, since it involves lyophilization and redissolution of wine; furthermore, $50 \%$ wine usually produces most of the inhibition found in $100 \%$ wine as observed using $\beta$-glucosidase from Endozym Rouge in Torrontés and Tannat wine (Cid \& Ellenrieder, 2009).

The $\beta$-glucosidases from the three preparations sold for aroma enhancement exhibited a higher relative activity in wine than the $\beta$-glucosidase from Endozym Rouge. The activity from Endozym $\beta$-split was the least inhibited.

Although all of the preparations showed similar quantities of glycosidase activities, with relatively low levels of $\alpha$-rhamnosidase, this result suggests that at least the $\beta$-glucosidase from the specific enzymes for aroma improvement would probably have a better activity when added to wine than the preparations used for other purposes, as was expected.

Since the presence of $\alpha$-arabinosidase is necessary for the hydrolysis of glycosides containing arabinose in the sugar moiety, the effect of $50 \%$ of Tannat wine in the reaction medium on Endozym $\beta$-split and Endozym Rouge $\alpha$-arabinosidase using $p$ NPA was also tested.

Table 3 shows that both enzymes maintained a significant percentage of their activity observed in buffer under the same conditions when $50 \%$ of wine was added to the medium. Even though the behavior of the $\alpha$-arabinosidase of Endozym $\beta$-split was slightly better than that of Endozym Rouge, both presented values comparable to those of the $\beta$-glucosidases from the preparations to enhance wine aroma. 
TABLE 2

$\beta$-Glucosidase activity from commercial enzymes at $50^{\circ} \mathrm{C}$ on $2 \mathrm{mM} p$-NPG in buffer at $\mathrm{pH} 3.6$ and in the presence of $50 \%$ of Tannat wine.

\begin{tabular}{lccc}
\hline \multirow{2}{*}{ Enzyme $\beta$-glu } & \multicolumn{2}{c}{ Activity (U/mL) } & \multirow{2}{*}{ Relative activity (\%) } \\
\cline { 2 - 3 } & Buffer pH 3,6 & Tannat wine (50\%) & $35.6 \pm 7.4$ \\
Endozym cultivar & $0.058 \pm 0.012$ & $0.018 \pm 0.003$ & $36.6 \pm 6.0$ \\
Endozym ICS 10 Arome & $0.250 \pm 0.025$ & $0.086 \pm 0.002$ & $42.6 \pm 2.3$ \\
Endozym $\beta$-split & $0.303 \pm 0.007$ & $0.129 \pm 0.009$ & $8.8 \pm 1.7$ \\
Endozym Rouge & $0.148 \pm 0.003$ & $0.013 \pm 0.003$ & \\
\hline
\end{tabular}

Relative activity is (activity in wine/activity in buffer under the same conditions) $\times 100$. Buffer: $60 \mathrm{mM}$ tartaric acid/Na tartrate

TABLE 3

$\alpha$-Arabinosidase activity from Endozym $\beta$-split and Endozym Rouge on $1 \mathrm{mM} p \mathrm{NPA}$ at $50^{\circ} \mathrm{C}$ in buffer at $\mathrm{pH} 3.6$ and in presence of $50 \%$ of Tannat wine.

\begin{tabular}{lccc}
\hline \multirow{2}{*}{ Enzyme } & \multicolumn{2}{c}{ Activity $(\mathrm{U} / \mathrm{mL})$} & \multirow{2}{*}{ Relative activity $(\%)$} \\
\cline { 2 - 4 } & Buffer $\mathrm{pH} \mathrm{3.6}$ & Tannat wine $(50 \%)$ & $47.5 \pm 9.3$ \\
Endozym $\beta$-split & $0.23 \pm 0.06$ & $0.11 \pm 0.01$ & $35.9 \pm 0.1$ \\
Endozym Rouge & $0.23 \pm 0.01$ & $0.084 \pm 0.003$ & \\
\hline R
\end{tabular}

Relative activity is (activity in wine/activity in buffer under the same conditions) $\times 100$. Buffer: $60 \mathrm{mM}$ tartaric acid/Na tartrate

\section{Glycoside hydrolysis in Tannat wine with different enzyme concentrations}

A preliminary assessment of glycosidase activity, inhibition and stability could be done using $p$-nitrophenylglycosides to select the enzymes displaying better performance. However, in order to evaluate the characteristics and kinetics of the hydrolysis of the glycosidic precursors produced by the selected exogenous glycosidases, complex procedures for the extraction and quantification of glycosides and aromas, including liquid and gas chromatography, are necessary (Cabaroglu et al., 2003; Rocha et al., 2005; Valcárcel \& Palacios, 2008). The use of these procedures on a routine basis, especially when a lot of enzyme preparations are being tested, is not practical. For this reason, the proposed method by Arévalo Villena et al. (2006) based on the determination of the whole glycosides, offers results appropriate to estimate the effectiveness of an enzyme treatment on the hydrolysis of aroma precursors in wines, allowing one to discard the enzymes displaying a negative or a very low level of glycoside hydrolysis.

The enzyme activity on their natural substrates was evaluated by measuring total glycoside concentration as a function of time. Glycosides were extracted from wine and then quantified by the determination of the glucose released after acid hydrolysis.

The effectiveness of the enzymatic hydrolysis of wine precursors depends on enzyme characteristics (rapid inhibition and long term stability) and the type of wine to be treated (inhibitor content and quantity); for this reason, the optimum concentration of enzyme may also be very variable. When a dose is recommended, it would provide enough glycosidase activity for the most unfavorable cases. However, according to the data shown in Table 1, manufacturers advise doses for the enzymatic preparations used to enhance wine aroma that are about five to ten times lower than those used in earlier studies of this subject (Gunata et al., 2000; Martino et al., 2000).

Endozym $\beta$-split was selected to study its effect on the glycosides of Tannat wine because it presents two of the glycosidase activities necessary for wine aroma enhancement, $\beta$-glucosidase and $\alpha$-arabinosidase, with low inhibition. However, $\alpha$-rhamnosidase activity was negligible in this commercial preparation and for this reason it was supplemented with the enzyme HPS 11518, which contains an $\alpha$-rhamnosidase that shows low inhibition and high stability in Tannat wine (Cid \& Ellenrieder, 2009). The presence of $\alpha$-rhamnosidase is necessary for the release of the aglycone from glycosides with rhamnose in their structure. In a preliminary study, an expert panel in a local winery found that Tannat wines treated with $\alpha$-rhamnosidase presented a better bouquet that those treated in the absence of this activity (data not shown), suggesting that its presence is important for aroma release.

The hydrolysis of Tannat wine glycosides was compared using two different concentrations of enzymes: the first as recommended by the manufacturers of Endozym $\beta$-split and the second based upon data published previously (Gunata et al., 2000; Martino et al., 2000). The glycoside concentration was measured before the treatment and after 12 days of incubation in a control sample of wine without added enzymes and in both samples treated with different amount of enzymes. The total glycoside concentration in the wine before the treatment was $313 \pm 27 \mathrm{nmol} / \mathrm{mL}$, and it was $308 \pm 1 \mathrm{nmol} / \mathrm{mL}$ in the control sample without enzyme added after 12 days, showing that glycosides did not break down by acid hydrolysis or hydrolysis by endogenous enzymes during this incubation period. On the other hand, the total glycoside concentrations after incubation of the wines treated with the enzymes were $320 \pm 35 \mathrm{nmol} / \mathrm{mL}$ and $221 \pm 1 \mathrm{nmol} / \mathrm{mL}$ when the dose was that recommended by the manufacturers and by published data, respectively. This result indicates that the amount recommended in the enzyme brochures was not enough to hydrolyze the glycosides present in Tannat wine and so the aromatic precursors, while using a significantly higher amount of the enzyme preparation achieved the desired effect. Rocha et al. (2005) studied the effect of adding an enzyme preparation to Maria Gomez and Bical wines during bottling at the dose 
TABLE 4

Physico-chemical parameters in samples of wine with and without enzymatic treatment.

\begin{tabular}{lcccccc}
\hline Sample & $\begin{array}{c}\text { Volatile acidity } \\
(\mathrm{g} / \mathrm{L})\end{array}$ & $\begin{array}{c}\text { Total acidity } \\
(\mathrm{g} / \mathrm{L})\end{array}$ & $\mathrm{pH}$ & $\begin{array}{c}\text { Alcohol level } \\
(\%)\end{array}$ & $\begin{array}{c}\text { Reducing } \\
\text { sugars }(\mathrm{g} / \mathrm{L})\end{array}$ & $\begin{array}{c}\text { Dry extract } \\
(\mathrm{g} / \mathrm{L})\end{array}$ \\
\hline Wine control & $0.73 \pm 0.01$ & $5.05 \pm 0.07$ & $3.68 \pm 0.04$ & $13.4 \pm 0.1$ & $4.75 \pm 0.06$ & $38.6 \pm 0.2$ \\
Enzyme-treated wine & $0.72 \pm 0.01$ & $5.81 \pm 0.13$ & $3.64 \pm 0.05$ & $13.4 \pm 0.2$ & $5.15 \pm 0.21$ & $38.0 \pm 0.1$ \\
\hline
\end{tabular}

recommended by the manufacturer. They measured the total amount of volatile compounds one year later in both wines and found that it increased by $9 \%$ in Maria Gomez wine but remained unchanged in Bical wine. This result could be explained by the fact that the amount of enzyme was not enough, as this study observed. Arévalo Villena et al. (2006) obtained similar results when testing a commercial preparation in three wines using the recommended doses. They measured the concentration of glycosidic precursors after the enzymatic treatment and it was slightly lower in two wines and no difference was observed in the third. One year later, Arévalo Villena et al. (2007) studied the hydrolysis of glycosides in two wines produced by a purified yeast extract showing $\beta$-glucosidase activity and found that 59 and $63 \%$ of the total glycosides were hydrolyzed, while the levels ranged from 21.5 to $32.6 \%$ when the wines were treated with a commercial enzyme for 12 days.

\section{Sensory analysis}

Even though the determination of the total glycoside concentration after the enzymatic hydrolysis informs whether the enzymes have acted upon them, the assay is not specific and all of the glycosides present are quantified by this assay, not only the aroma precursors. For this reason, a preliminary sensory analysis was performed to determine whether wine aroma was modified after the treatment with exogenous glycosidases, which would indicate if some of the glycosides hydrolyzed by the enzymes were aroma precursors.

Of the possible discriminative analyses, the triangle test was selected because it is commonly used to detect if perceptible changes are produced in wines after introducing some modification in the process (Cabaroglu et al., 2003; Zocca et al., 2008; Ruiz et al., 2010).

A total of 32 triangles were performed. The results indicated that there was a significant difference between the controls and the enzyme-treated wines $(P=0.01)$. Taking into account only the correct answers, an analysis of frequency of mention of attributes was carried out. The assessors found differences in sourness, astringency and aroma intensity between the wines with and without enzyme treatment. Nine of them described the wines without enzyme treatment sourer and six more astringent, while six mentioned that the enzyme-treated wines had higher aroma intensity. According to these results, it can be assumed that at least a part of the hydrolyzed glycosides were aroma precursors.

\section{Physico-chemical determination}

Some physico-chemical assays were carried out on a treated wine sample and on a wine control after 12 days of incubation to observe if the enzymatic treatment produced any modification. The results are shown in Table 4.

The ANOVA tests indicated that there were no significant differences in the measured parameters except in the total acidity $(P<0.05)$, which was higher in the enzymetreated wine. However, the increase in the total acidity was not enough to produce a modification of the $\mathrm{pH}$ of the wine or be detected during sensory testing by the assessors. It is important to note that the total acidity in both samples was in the order of the values reported in many studies (Izquierdo Cañas et al., 2008; Todaro et al., 2008).

\section{CONCLUSIONS}

The use of the easy and quick methods described showed that three enzymatic preparations studied in this work presented high $\beta$-glucosidase and $\alpha$-arabinosidase activities and low levels of $\alpha$-rhamnosidase. Taking into account the recommended doses for use of these preparations, the total glycosidase activity that would be added to the wine does not seem to be enough to produce a detectable hydrolysis. All of the preparations should be supplemented with $\alpha$-rhamnosidase in order to release all the precursors, especially those containing rhamnose in their structure.

The presence of glycosidase activity as determined with synthetic substrates is not enough to state that a commercial enzyme would produce an aroma improvement. However, the $\beta$-glucosidases from three preparations studied retained their activity in the presence of Tannat wine.

The selected enzyme Endozym $\beta$-split, supplemented with $\alpha$-rhamnosidase activity from HPS 11518, produced an appreciable hydrolysis of the glycosidic precursors present in Tannat red wine. However, considerably higher amounts were necessary than the dose recommended by the manufacturers to produce glycoside hydrolysis to achieve the desired effect. At least a part of the hydrolyzed glycosides were aroma precursors, since the enzymatic treatment produced a detectable modification in the wine, which was described by some assessors as an increase in aroma intensity.

\section{LITERATURE CITED}

ASTM, 1977. Manual on Sensory Testing and Methods, STP 434. In: American Society for Testing and Materiales, Philadelphia, PA, pp. 39-40.

Arévalo Villena, M., Díez Pérez, J., Úbeda, J.F., Navascués, E., Briones, A.I., 2006. A rapid method for quantifying aroma precursors: Application to grape extract, musts and wines made from several varieties. Food Chem. 99, 183-190.

Arévalo Villena, M., Úbeda Iranzo, J.F., Briones Pérez, A.I., 2007. b-Glucosidase activity in wine yeasts: Application in enology. Enzyme Microb. Tech. 40, 420-425.

Armada, L., Fernández, E., Falqué, E., 2010. Influence of several enzymatic treatments on aromatic composition of white wines. LWT-Food Sci. Technol. 43, 1517-1525.

Association of Official Analytical Chemists (AOAC), 1990. Methods 920.57, 920.62, 920.64, 920.69A y 920.19. In: Herlich, K. (ed), Official Methods, Arlington, Virginia Wines. 
Barbagallo, R.N., Spagna, G., Palmeri, R., Restuccia, C., Giudici, P., 2004 Selection, characterization and comparison of b-glucosidase from mould and yeasts employable for enological applications. Enzyme Microb. Tech. $35,58-66$.

Boido, E., Lloret, A., Medina, K., Carrau, F., Dellacassa, E., 2002. Effect of b-glycosidase activity of Oenococcus oeni on the glycosylated flavor precursors of Tannat wine during malolactic fermentation. J. Agr. Food Chem. 50, 2344-2349.

Boido, E., Lloret, A., Medina, K., Fariña, L., Carrau, F., Versini, G., Dellacassa, E., 2003. Aroma composition of Vitis vinifera cv. Tannat: the typical red wine from Uruguay. J. Agr. Food Chem. 51, 5408-5413.

Cabaroglu, T., Selli, S., Canbas, A., Lepoutre, J.P., Gunata, Z., 2003. Wine flavor enhancement through the use of exogenous fungal glycosidases. Enzyme Microb. Tech. 33, 581-587.

Cid, A.G., Ellenrieder, G., 2009. Inhibition and inactivation evaluation of exogenous glycosidases in wines using $p$-nitrophenylglycosides. J. Sci Food Agr. 89, 1053-1059.

Dupin, I., Gunata, Z., Sapis, J.C., Bayonove, C.L., M'Bairaroua, O., Tapiero, C., 1992. Production of b-apiosidase by Aspergillus niger: Partial purification, properties, and effect on terpenyl apiosylglucosides from grape. J. Agr. Food Chem. 40, 1886-1891.

Guérin, L., Sutter, D.H., Demois, A., Chereau, M., Trandafir, G., 2009. Determination of activity profiles of the main commercial enzyme preparations used in winemaking. Am. J. Enol. Vitic. 60, 322-331.

Gunata, Z., Bitteur, S., Brillouet, J.M., Bayonove, C., Cordonnier, R., 1988. Sequential enzymic hydrolysis of potentially aromatic glycosides from grape. Carbohyd. Res. 184, 139-149.

Gunata, Z., Bitteur, S., Baumes, R., Brillouet, J.M., Tapiero, C., Bayonove, C., Cordonnier, R., 2000. Process for obtaining aroma components and aroma from their precursors of glycosidic nature, and aroma components and aromas thereby obtained. USA Patent 6,106,872.

Gunata, Z., Dugelay, I., Vallier, M.J., Sapis, J.C., Bayonove, C., 1997. Multiple forms of glycosidases in an enzyme preparation from Aspergillus niger: Partial characterization of a b-apiosidase. Enzyme Microb. Tech. 21, $39-44$.

Gunata, Z.Y., Bayonove, C.L., Baumes, R.L., Cordonnier, R., 1985. The aroma of grapes. I Extraction and determination of free and glycosidically bound fractions of some grape aroma components. J. Chromatogr. 331, 8390 .

Guo, W., Salmon, J.M., Baumes, R., Tapiero, C., Gunata, Z., 1999. Purification and some properties of an Aspergillus niger b-apiosidase from an enzyme preparation hydrolyzing aroma precursors. J. Agr. Food Chem. 47, 2589-2593.

Izquierdo Cañas, P.M., García Romero, E., Gómez Alonso, S., Palop Herreros, M.L.L., 2008. Changes in the aromatic composition of Tempranillo wines during spontaneous malolactic fermentation. J. Food Compos. Anal. $21,724-730$.

Le Clinche, F., Pinaga, F., Ramon, D., Valles, S., 1997. a-LArabinofuranosidases from Aspergillus terreus with potential application in enology: induction, purification, and characterization. J. Agr. Food Chem. 45, 2379-2383.
Le Traon-Masson, M.P., Pellerin, P., 1998. Purification and characterization of two b-D-glucosidases from an Aspergillus niger enzyme preparation: affinity and specificity toward glucosylated compounds characteristic of the processing of fruits. Enzyme Microb. Tech. 22, 374-382.

Martino, A., Durante, M., Pifferi, P.G., Spagna, G., Bianchi, G., 1996. Immobilization of b-glucosidase from a commercial preparation. Part 1. A comparative study of natural supports. Process Biochem. 31, 281-285.

Martino, A., Schiraldi, C., Di Lazzaro, A., Fiume, I., Spagna, G., Pifferi, P.G., De Rosa, M., 2000. Improvement of the flavour of Falanghina white wine using a purified glycosidase preparation from Aspergillus niger. Process Biochem. 36, 93-102.

Michlmayr, H., Schümann, C., Barreira Braz da Silva, N.M., Kulbe, K.D., Del Hierro, A.M., 2010. Isolation and basic characterization of a b-glucosidase from a strain of Lactobacillus brevis isolated from a malolactic starter culture. Journal of Appl. Microbiol. 108, 550-559.

Pogorzelski, E., Wilkowska, A., 2007. Flavour enhancement through the enzymatic hydrolysis of glycosidic aroma precursors in juices and wine beverages: a review. Flav. Frag. J. 22, 251-254.

Rocha, S.M., Coutinho, P., Delgadillo, I., Dias Cardoso, A., Coimbra, M.A., 2005. Effect of enzymatic aroma release on the volatile compounds of white wines presenting different aroma potentials. J. Sci. Food Agr. 85, 199-205.

Ruiz, P., Izquierdo, P.M., Seseña, S., Palop, M.L., 2010. Selection of autochthonous Oenococcus oeni strains according to their oenological properties and vinification results. Int. J. Food Microbiol. 137, 230-235.

Saha, B.C., 2000. $\alpha$-L-Arabinofuranosidases: biochemistry, molecular biology and application in biotechnology. Biotechnol. Adv. 18, 403-423.

Sánchez Palomo, E., Díaz-Maroto, M.C., Gonzáles-Viñas, M.A., PérezCoello, M.S., 2005. Aroma enhancement in wines from different grape varieties using exogenous glycosidases. Food Chem. 92, 627-635.

Sarry, J.E., Gunata, Z., 2004. Plant and microbial glycoside hydrolases: Volatile release from glycosidic aroma precursors. Food Chem. 87, 509521.

Tamborra, P., Martino, N., Esti, M., 2004. Laboratory tests on glycosidase preparations in wine. Anal. Chim. Acta 513, 299-303.

Todaro, A., Palmeri, R., Barbagallo, R.N., Pifferi, P.G., Spagna, G., 2008. Increase of trans-resveratrol in typical Sicilian wine using b-Glucosidase from various sources. Food Chem. 107, 1570-1575.

Valcárcel, M.C., Palacios, V., 2008. Influence of 'Novarom G' Pectinase $\beta$-glycosidase enzyme on the wine aroma of four white varieties. Food Sci. Technol. Int. 14, 95-102.

Williams, P.J., Straus, C.R., Wilson, B., Massy-Westropp, R., 1982. Novel monoterpene disaccharide glycosides of Vitis vinifera grapes and wines. Phytochem. 21, 2013-2120.

Williams, P., Cynkar, W., Francis, L., Gray, J., Lland, P., Coombe, B., 1995. Quantification of glycosides in grape juice and wines through determination of glycosyl glucose. J. Agr. Food Chem. 43, 121-128.

Zocca, F., Lomolino, G., Spettoli, P., Lante, A., 2008. A study on the relationship between the volatile composition of Moscato and Prosecco Grappa and enzymatic activities involved in its production. J. I. Brewing $114,262-269$ 